\title{
Prevalence and risk factors associated with serovars of Leptospira in dogs, related human seropositive
}

\begin{abstract}
To determine the seroprevalence and the main risk factors associated with serovars of Leptospira in dogs from Culiacan, Sinaloa, we obtained serum from the blood samples of $106 \mathrm{dogs}$, related humans seropositive (blood donors of public hospitals). The samples were stored at $-40{ }^{\circ} \mathrm{C}$ until use and were analyzed by the microbiology laboratory of the Centro Nacional de Sanidad Animal (CENASA) using the leptospirosis microscopic agglutination test (MAT). An epidemiological survey was conducted in order to identify risk factors. Statistical analyzes were done using the chisquare test. The risk (OR: odds ratio) and the confidence intervals were calculated using the logistic regression model. A value of $\mathrm{P}<0.05$ was considered statistically significant. The prevalence of Leptospira was $17 \%(18 / 106)$, and we identified eleven serovars and their respective frequency: wolffi $(66.6 \%)$, bratislava $(22.2 \%)$, australis $(16.6 \%)$, canicola $(11.1 \%)$, grippotyphosa $(11.1 \%)$, pyrogenes $(11.1 \%)$, hardjo $(5.5 \%)$, icterohaemorragiae $(5.5 \%)$, pomona $(5.5 \%)$, hebdomadis $(5.5 \%)$, shermani $(5.5 \%)$. The risk factors associated with the detection of antibodies to this bacteria, based on epidemiological surveys, include the sex of pets female $(\mathrm{P}<0.05 ; \mathrm{OR}=2.9)$ and the dogs who stay at home and have access to the street was marginally significant $(\mathrm{P}=0.06)$.
\end{abstract}

Keywords: leptospirosis, leptospira, dog, prevalence, risk factors, blood donors
Volume 6 Issue 2 - 2017

\author{
Carlos Víctor Hernández Ramírez, ${ }^{1,2}$ Soila \\ Maribel Gaxiola Camacho,' Idalia Enríquez \\ Verdugo,' Ignacio Osuna Ramírez, ${ }^{3}$ and José \\ Ramón Rivas Llamas ${ }^{4}$ \\ 'Laboratorio de Parasitología, Universidad Autónoma de Mexico \\ ${ }^{2}$ Departamento de Prevención y Control de Vectores y \\ Zoonosis, Mexico \\ ${ }^{3}$ Unidad de Investigaciones en Salud Pública Facultad de Ciencias \\ Químico Biológicas de la Universidad Autónoma de Sinaloa, \\ Mexico \\ ${ }^{4}$ Departamento de Hemovigilancia, Mexico
}

\begin{abstract}
Correspondence: Soila Maribel Gaxiola Camacho, Faculty of Veterinary Medicine, Autonomous University of Sinaloa, Boulevard San Angel s/n San Benito Culiacan, Sinaloa, Mexico, Tel 6677181650,Email soilagaxiola@uas.edu.com.mx, mvzhernandez_sin@hotmail.com.mx
\end{abstract}

Received: October 13,2017 | Published: December 05, 2017

\section{Introduction}

Leptospirosis is the most widespread zoonotic disease in the world, with great economic and health importance. Infection is typically transmitted through direct contact of oral or nasal mucosa, with contaminated urine or water, and dogs are at risk of infection from drinking contaminated water. ${ }^{1,2}$ Dogs play an important role as potential indicators of areas with high endemicity for leptospirosis. Thus, recognizing and preventing canine leptospirosis has implications for human health as well as dogs. ${ }^{3}$ This disease is caused by a spirochete of pathogenic strains of the genus Leptospira, affecting wild and domestic animals, as well as man. Despite being a treatable disease, human leptospirosis is a significant public health problem.

Leptospires are classified into pathogenic, non-pathogenic, and intermediate species based on DNA hybridization. The old phenotypic classification system based on agglutination absorption test identified approximately 250 serovars among the Leptospira species and serogroups ${ }^{4}$ Humans are incidental hosts and get infected by exposure to an environment contaminated with the urine of an animal reservoir. Leptospires are strictly aerobic microorganisms. Morphologically, they are spirochetes that are approximately $0.1 \mu \mathrm{m}$ wide and $6-15 \mu \mathrm{m}$ long, with flexion, translation, and propulsion movements, as well as active ondulation. These bacteria are Gram-negative and divide by binary fission. Leptospira spp. are spiroquetes that can rapidly move through the blood, reaching the kidneys, heart, lungs and liver. These bacteria damage tissues while moving within organs and can cause multiorganic failure in a few weeks. ${ }^{5,6}$

Rodents are the most frequent reservoirs, with wild carnivores, no mammal can be excluded as a possible host. ${ }^{8}$ The pathogenic Leptospira lives in the proximal renal tubules of the kidneys of carriers, ${ }^{9,10}$ other tissues and organs may serve as a source of infection. From the kidneys, leptospires are excreted into the urine and can contaminate mud, water, streams and rivers ${ }^{11}$ for this reason; this disease is occasionally epidemic outbreak, especially in situations of great abundance of rodents and floods. ${ }^{12}$ The diagnosis of leptospirosis is performed by various methods, however, plate micro agglutination (MAT) is regarded as the gold standard. The reactions determine the presence of agglutinating antibodies against the tested serovars. ${ }^{13}$ Antibodies generally appear between the sixth and twelfth day of infection and increase rapidly until the second or fourth week, subsequently manifesting a gradual decline of levels. ${ }^{14}$

The main source of infection for animals, especially dogs, is the urine of asymptomatic carrier animals (dog to $\mathrm{dog}$ ), as well as vectors, rodents being a natural reservoir. ${ }^{15,16}$ The serovars icterohaemorrahgiae and pomona produce hemolysins, which are responsible for hemoglobinuria. In the case of the serovar icterohaemorrahgiae, it causes severe jaundice in dogs. Person-to-person transmission is exceptional, but several cases of congenital infection have been described. Furthermore, a case of transmission through breast milk has been described in the United States. In Mexico, serological studies have been carried out in dogs from various states of the country. Moles et al. ${ }^{17}$ analyzed sera from a total of 218 dogs from the antirabies center of Culhuacán, Mexico City, and found that $28.44 \%$ were seropositive to one or more serovars; Leptospira canicola was the most prevalent, with $22 \%$ seropositivity. Flores \& Solana, ${ }^{18}$ observed a frequency of seropositivity of $61.7 \%$ in all dogs studied. In the same year, Garcia \& Ibarra, ${ }^{19}$ found $41.5 \%$ seropositivity in dogs from Toluca, in the State of Mexico. Luna, ${ }^{20}$ analyzed a total of 485 sera from dogs in the area of Naucalpan, State of Mexico, and found $48.4 \%$ seropositivity. The main source of infection for animals, and dogs in particular, is the urine of asymptomatic carrier animals, and vectors, of which the most important are rodents, due to their capacity to act as natural reservoir for the bacteria. Dogs are considered the most important domestic species in the transmission 
of leptospirosis to man. ${ }^{21}$ In the state of Sinaloa, this disease has been diagnosed in humans, ruminants and pigs. ${ }^{22}$ The real extent of the disease is unknown, as is the presence of leptospira serovars in dogs. Thus, it is important to determine the seroprevalence of the disease and to identify risk the factors associated with serovars of Leptospira Interrogans in dogs of Culiacan, Sinaloa, this information could help find alternatives for controlling the disease. The state of Sinaloa is endemic zone of Leptospirosis, and occupies the first National place in mortality by this disease with 117 deaths in the period 2005-2014 ( $48 \%$ of lethality). As for morbidity, it occupies the third national place with 201 cases in the mentioned period below only the states of Tabasco and Veracruz. ${ }^{23}$ Leptospirosis in dog is caused by L. canicola and L. icterohaemorrahgiae, these two serovars are considered in some areas, the most important in this species. ${ }^{24,25}$ Other serovars are considered accidental transmitted by wildlife, ${ }^{26}$ it manifests mainly in subclinical form, so that the serological findings are more frequent than the manifestation of the disease, however when it is present, it can cause death, the recovered animals remain in the carrier for months or years. ${ }^{27,28}$ In 1916, the first report published highlighting the importance of canine leptospirosis in public health by observing Weill's disease in two individuals who had been in contact with an icteric dog. ${ }^{29,30}$ The dog has been identified as the most important domestic species in the transmission of leptospirosis to man. ${ }^{27,29,31,32}$

Infection in dogs by serovar canicola is considered the most common, serovar icterohaemorrahgiae is less frequent and is related to the rats as carrier and transmitter. ${ }^{33-36}$ Leptospirosis can be transmitted after a subclinical or clinical infection, as well as in the last stage of acute disease and the chronic phase, since infected dogs excrete leptospires through the urine. The quantity of leptospires is greater in the first weeks post-infection and elimination can last up to four years, thus achieving the transmission of animal to animal and animal to human. ${ }^{27,37}$ The habits of dogs (sniffing, lick, cortege), and the places where they habit favor the transmission of infection and dog-to-dog disease. ${ }^{38-40}$

\section{Materials and methods}

This study was conducted in the city of Culiacan, Sinaloa, Mexico, located at $24^{\circ} 48^{\prime} \mathrm{N}$ and $107^{\circ} 23^{\prime} \mathrm{W}, 60$ meters above sea level; the climate of the region is classified as semi-dry, with a very warm average temperature of $25.5^{\circ} \mathrm{C}$, maximum temperatures of $45^{\circ} \mathrm{C}$ in the months of July and August, minimum temperatures of $7^{\circ} \mathrm{C}$ in December and January, and an annual rainfall of $671.14 \mathrm{~mm}$. Blood samples were collected from 106 canine in domicile and colonies where seropositive blood donors from public hospitals in Culiacán, Sinaloa were identified, the dogs not vaccinated against leptospirosis. Before taking the blood samples, we applied a questionnaire to the pet owners in order to obtain their address and information related to the conditions and characteristics of the place where the dogs lived; the questions were directly related to the epidemiological variables that are determining factors in the transmission of leptospirosis.

We also asked for their authorization to take the blood samples through an informed consent form; the samples $(3 \mathrm{ml})$ were obtained by puncturing the jugular vein, were deposited in a vacutainer tube without anticoagulant and centrifuged for five minutes at $1008 \mathrm{~g}$. The blood was free of pollutants, not hemolyzed, and the serum samples thus obtained were frozen at $-40^{\circ} \mathrm{C}$ in an ultra-freezer. Once collected, the samples were taken to the laboratory of the National Animal Health Centre in Tecamac, State of Mexico, where they were processed using the Microscopic Agglutination Test (MAT), with specific reactions for each serovar; we used a panel that included the following serovars: ballum, canicola, hardjo, pomona, pyogenes, icterohaemorrhagiae, bratislava, wolffi, australis, grippotyphosa, hebdomadis and shermani, 106 samples were taken in vacutainer tubes without anticoagulant; they were centrifuged for five minutes at $1008 \mathrm{~g}$ to obtain serum, which was then frozen. The cut-off points of the tests considered titers of 1:100 or greater as positive. The questionnaire asked for the name of the owner, address, number of dogs per owner, sex, race, age, vaccinations applied place of habitation, types of floor, presence of rodents, water supply in the house, presence of pools, open water containers, presence of drainage and number of residents per dwelling. We performed a transversal analytical study. An epidemiological survey was applied to the people responsible for the dogs in order to identify risk factors. The homogeneity of proportions was tested using the chi-square statistic test; the risks (OR, odds ratio) and the confidence intervals were estimated using the logistic regression model. A value of $\mathrm{P}<0.05$ was considered statistically significant. All analyzes were performed using the statistical package Stata Intercooled V.13.1.

\section{Results and discussion}

We studied 106 serological samples from dogs associated with seropositive blood donors from public hospitals of Culiacán, resulting in 18 canine positive cases. The descriptive analysis of the survey data indicates the number of pets with owner was $96 \%$ as well as 201 dogs related to sampled animals and 444 humans. The age data sampled indicate that $53 \%$ were taken from animals older than two years, and $47 \%$ pets under that age. Regarding the type of dog breed, we found that $50 \%$ of the serum samples corresponded to mixed breeds, followed by crosses of small breeds such as poodle and chihuahua (29\%); these two groups made up $79 \%$ of the samples, the sex of the sampled animals, $55 \%$ correspond to males and $45 \%$ to females. The place of habitation of the dogs was also considered an important factor related to the epidemiology of the disease; $94.34 \%$ of the dogs lived within the home, while $53 \%$ of the sampled dogs had contact with the street. We observed that $10.38 \%$ of the dogs remained inside the house, $38.68 \%$ inhabited both the interior and exterior of the house, and the majority $(45.28 \%)$ remained only in courtyards. Regarding the type of floor in the place inhabited by the dogs, $36 \%$ corresponded to cement and $39 \%$ to cement and dirt; the rest of the animals stayed only on dirt (25\%). With regard to the water supply in the homes, $88 \%$ have piped water, and $12 \%$ reported using drums or basins for water storage.

Drainage was present in $90 \%$ of the households. Regarding the number of people living in each household, the most frequent value was five residents per household $(25.47 \%)$, followed by households with four inhabitants $(23.58 \%)$ as well as other with less people. Rodents were reported in $75 \%$ of the households. A serological study of 106 samples from dogs living in the city of Culiacan, Sinaloa, indicated a prevalence of Leptospira Interrogans of 17\%; the serovars detected were: wolffi, bratislava, australis, canicola, grippotyphosa, pyrogenes, hardjo, icterohaemorragiae, pomona, hebdomadis y shermani (Table 1). The observed frequency for serovars, from high to low was: Wolffi $66.6 \%$, Bratislava $22.2 \%$, Australis $16.6 \%$, Canicola $11.1 \%$, Grippotyphosa $11.1 \%$, Pyrogenes $11.1 \%$, Hardjo 5.5\% Icterohaemorragiae 5.5\%, Pomona 5.5\%, Hebdomadis 5.5\%, Shermani 5.5\% (Figure 1). 
Table I Sorovars leptospira interrogans identified in dogs

\begin{tabular}{|c|c|c|}
\hline Sample number & Serovar & Títles \\
\hline \multirow[t]{5}{*}{$\mathrm{Cl}-05$} & Canicola & 0.319444 \\
\hline & Pomona & 0.111111 \\
\hline & Bratislava & 0.111111 \\
\hline & Grippotyphosa & 0.319444 \\
\hline & Pyrogenes & 0.597222 \\
\hline \multirow[t]{6}{*}{ C4-04 } & Grippotyphosa & 0.180556 \\
\hline & Icterohaemorrahagie & 0.111111 \\
\hline & Bratislava & 0.180556 \\
\hline & Canicola & 0.180556 \\
\hline & Pyrogenes & 0.319444 \\
\hline & Hardjo & 0.111111 \\
\hline C5-0I & Wolffi & 0.180556 \\
\hline C5-02 & Wolffi & 0.180556 \\
\hline C5-03 & Wolffi & 0.180556 \\
\hline C5-04 & Wolffi & 0.180556 \\
\hline \multirow[t]{2}{*}{ C5-05 } & Wolffi & 0.319444 \\
\hline & Australis & 0.111111 \\
\hline C5-06 & Wolffi & 0.111111 \\
\hline \multirow[t]{2}{*}{ C5-07 } & Wolffi & 0.111111 \\
\hline & Shermani & 0.111111 \\
\hline \multirow[t]{2}{*}{ C5-08 } & Wolffi & 0.180556 \\
\hline & Australis & 0.111111 \\
\hline C5- 10 & Wolffi & 0.111111 \\
\hline \multirow[t]{2}{*}{ C5-I5 } & Australis & 0.11111 \\
\hline & Shermani & 0.111111 \\
\hline \multirow[t]{2}{*}{ C5- 17} & Wolffi & 0.11111 \\
\hline & bratislava & 0.180556 \\
\hline \multirow[t]{4}{*}{ C5- 18} & Hebdomadis & 0.111111 \\
\hline & Bratislava & 0.111111 \\
\hline & Australis & 0.111111 \\
\hline & Wolffi & 0.180556 \\
\hline C5-19 & Wolffi & 0.180556 \\
\hline \multicolumn{3}{|l|}{ C6-0I } \\
\hline \multicolumn{3}{|l|}{ C8-03 } \\
\hline \multicolumn{3}{|l|}{$\mathrm{C} 8-13$} \\
\hline & Wolffi & 0.111111 \\
\hline & Wolffi & 0.111111 \\
\hline & Bratislava & $0.1 I I I I I$ \\
\hline
\end{tabular}

The epidemiological variables corresponding to neighborhoods (socioeconomic stratum), number of pets per household, dogs with or without owner age, breed, stay of pets type of floors water supply, drainage, water stored in drums and basins and presence of rodents showed no significant differences $(\mathrm{P}<0.05)$. There was a significant difference in the sex of pets female $(\mathrm{P}<0.05 ; \mathrm{OR}=2.9)$ and the dogs who stay at home and have access to the street was marginally significant $(\mathrm{P}=0.06)$. Serological positive samples were found in colonies with similar characteristics, of housing construction, access routes and similar socioeconomic status, unpaved streets with garbage presence in yards and street, with accumulation of "pots", with poor basic sanitation and poor management of stored water all these characteristics are risk factors for the disease. ${ }^{16}$

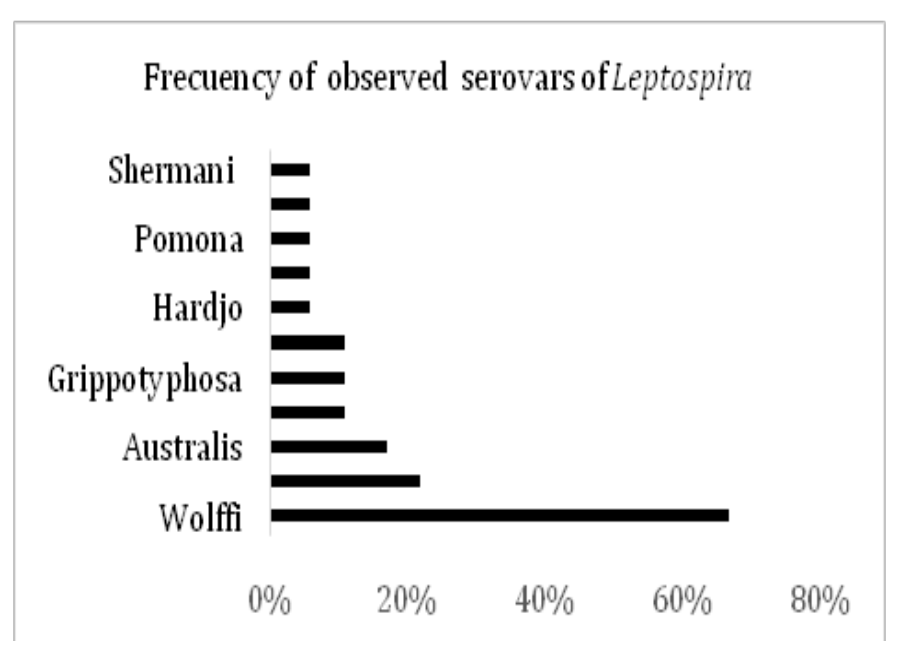

Figure I Frequency of observed serovars of Leptospira.

The eleven identified serovars include those mentioned as very pathogenic to humans of their characteristics of hemolysins production mainly by serovars Icterohaemorrahgiae and Pomona, which are responsible for hemoglobinuria and vascular damage. ${ }^{41}$ Positive animals no presents clinical signs characteristic of the disease and their owners not mention sigth them sick. We also observed the presence of multiple infections in a single host( up to six serovars). The vaccines conventionally applied in veterinary clinics in Culiacan usually include four serovars: canicola, grippotyphosa, icterohaemorrhagiae and pomona but the serovars, bratislava, pyrogenes, shermani, ballum, australis, hardjo y hebdomadis which were found in the study and are pathogenic to humans, are not included, creating the potential risk that pet owners could get infected by these serovars. ${ }^{42}$ The observed prevalence $(17 \%)$ is higher than that reported by Hernández et al. ${ }^{43}$ In Culiacan in apparently healthy dogs from a general population, without association with seropositive humans. However, it is close to that reported for Mexico by several authors in other studies were conducted with animals suspected of leptospirosis or at high risk, including stray dogs, animals in veterinary clinics and rabies centers, and dogs in close coexistence with domestic animals such as cattle, pigs, goats and sheep. ${ }^{44}$ The serovars vary from region to region, ${ }^{45}$ observed a predominance of the serovars autumnalis, icterohemorrhagiae and canicola in healthy dogs of the state of Washington, in Mexico in the state of Veracruz the serovars detect tarassovi, canicola pyrogenes y autumnalis with a seroprevalence of Sinaloa have detected 20 serovars between humans and animals, Studies in Mexico refer up to five serovars in dogs detected in the different regions studied ${ }^{46}$ unlike the eleven serovars found in this study. The sex of pets was also statistically significant $(\mathrm{P}<0.05 ; \mathrm{OR}=2.9)$, with females having a higher prevalence compared to males; ${ }^{40}$ Ward et al. ${ }^{41}$ reported male 
dogs used for work and shepherding are in greater risk of contracting the disease (Table 2). The dogs who stay at home and have access to the street was marginally significant $(\mathrm{P}=0.06)$, (Table 3$)$ to have contact with other animals, urine or contaminated water, can be inferred there is a greater risk of infected with bacteria. ${ }^{15,16,43,46}$

Table 2 Sex pets

\begin{tabular}{llll}
\hline Sex & Negative & Positive & Total \\
\hline Female & 36 & 12 & 48 \\
Male & 52 & 6 & 58 \\
Total & 88 & 18 & 106 \\
$\%$ & 83.02 & 16.98 & 100 \\
\hline
\end{tabular}

pearson chi-square, 4.00 I; GL, I; P value, 0.045

chi-square likelihood rate, 4.0 I9; GL, I; P value, 0.045

Table 3 Dogs have access to the street

\begin{tabular}{llll}
\hline Sex & Negative & Positive & Total \\
\hline Home/street & 43 & 13 & 56 \\
home & 45 & 5 & 50 \\
Total & 88 & 18 & 106 \\
$\%$ & 83.02 & 16.98 & 100 \\
\hline
\end{tabular}

pearson chi-square, 3.272; GL, I; P value, 0.070

chi-square likelihood rate, 3.389; GL, I; P value, 0.066

\section{Conclusion}

In the city of Culiacan Sinaloa, there are seropositive dogs to antileptospira interrogans antibodies related to seropositive humans associated to risk factors in the streets that favor the contact with the bacteria while maintaining the possibility of contagion to other animals and humans. The prevalence observed was higher in dogs associated with human cases, than in the general population, in the same area studied, it is probable that these animals have an important role in the transmission to humans.

\section{Acknowledgements}

i. Departamento de Parasitología de la Facultad de Medicina Veterinaria y Zootecnia Universidad Autónoma de Sinaloa.

ii. Unidad de investigaciones en salud Publica de la Facultad de Química de la Universidad Autónoma de Sinaloa

iii. Departamento de prevención y Control de Vectores y Zoonosis de los Servicios de Salud de Sinaloa.

\section{Conflict of interest}

The authors declare that there is no conflict of interest.

\section{References}

1. Nelson RW, Couto CG. Small Animal Medicine. 3rd ed. Mosby, St. Louis, USA; 2003.

2. Heymann D. Control of Communicable Diseases Manual. 19th ed. American Public Health Association, Washington, USA; 2008. p. 1-715.
3. White AM, Zambrana Torrelio C, Allen T, et al. Hotspots of canine leptospirosis in the United States of America. Vet J. 2017;222:29-33.

4. Brenner DJ, Kaufmann AF, Sulzer KR, et al. Further determination of DNA relatedness between serogroups and serovars in the family Leptospiraceae with a proposal for Leptospira alexanderi sp. nov. and four new Leptospira genomospecies. Int J Syst Bacteriol. 1999;49:839-858.

5. Levet PN. Leptospirosis. Clinical Microbiology Reviews. 2001;14(2):296-326.

6. Yalin W, Lingbing Z, Hongliang Y, et al. High prevalence of pathogenic Leptospira in wild and domesticated animals in an endemic area of China. Asian Pacific Journal of Tropical Medicine. 2011;4(11):841-845.

7. Hirsh DC, Mac Lachlan NJ, Walker RL. Veterinary Microbiology. 2nd ed. Ames, Iowa: Blackwell Publishing Professional 2121 State Avenue 50014; 2004:148-152.

8. Quinn P, Markey BK, Carter ME, et al. Veterinary Microbiology and Microbial Disease. 1st ed. UK: Blackwell Science Ltd, 9600 Garsington Road; 2002. p. 175-179.

9. Songer J, Post KW. Veterinary Microbiology: Bacterial and Fungal Agents of Animal Disease. 1st ed. St. Louis, Missouri: Elsevier Saunders; 11830 Westline Industrial Drive; 2005. p. 244-250.

10. Adler B, de la Peña Moctezuma A. Leptospira and Leptospirosis. Vet Microbiol. 2010;140(3-4):287-296.

11. Arango J, Cittadino E, Agostini A, et al. Prevalencia de leptospiras en Rattus rattus y Rattus norvegicus en el Gran Buenos Aires, Argentina. Ecología Austral. 2001;11:25-30.

12. Organización Mundial de la Salud (OMS). Leptospirosis humana: guía para el diagnóstico, vigilanciay control/Organización Mundial de la Salud. Traducción del Centro Panamericano de Fiebre Aftosa. Rio de Janeiro: Centro Panamericano de Fiebre Aftosa; 2008. p. 1-127.

13. Luna AM. Aspectos clínicos reportados en leptospirosis canina. Primer Seminario Taller Nacional sobre el diagnóstico y control de la leptospirosis. Mexico: Universidad Metropolitana Xochimilco; 1997. p. 23-25.

14. Alton GD, Berke O, Reid-Smith R, et al. Aumento de la seroprevalencia de leptospirosis y sus factores de riesgo, Ontario 1998-2006. Can J Vet Res. 2009;73(3):167-175.

15. Meeyam T, Tablerk P, Petchanok B, et al. Seroprevalence and risk factors associated with leptospirosis in dogs. Southeast Asian J Trop Med Public Health. 2006;37(1):148-153.

16. Moles CL, Salomón S, Munguía A. Estudio serológico para detectar anticuerpos contra Leptospira interrogans en perros de la ciudad de México. Memorias del XXI Congreso Nacional de Microbiología. Villahermosa Tabasco, Mexico; 1990. 39p.

17. Flores CR, Solana MP. Problemática de la Vacunación contra la Leptospirosis Canina. Memorias del XXII Congreso Nacional de AMVEPE. 5663.1992.

18. García SC, Ibarra ZS. Estudio serológico de Leptospirosis canina en la ciudad de Toluca. (Tesis de Licenciatura), Facultad de Medicina Veterinaria y Zootecnia Universidad Nacional Autónoma del Estado de México. 1992;51(2):1-11.

19. Luna AM. Frecuencia serológica de Leptospirosis canina en el Municipio de Naucalpan de Juárez, Estado de México. (Tesis de Licenciatura) Facultad de Medicina Veterinaria y Zootecnia UNAM, Mexico; 1993.

20. Venkataraman KS, Nedunchelliyan S. Epidemiology of an Outbreak of Leptospirosis in Man and Dog. Comp Inmun Microbiol Dis. $1992 ; 15(4): 243-247$. 
21. Luna AM, Moles CL, Gavaldón RD, et al. Estudio retrospectivo de seroprevalencia de leptospirosis bovina en México, considerando las regiones ecológicas. Rev Cub Med Trop. 2005;51(1):1-4.

22. DGIS Cubo de Defunciones 1979-2014/DGIS/ Secretaria de Salud (consultado julio 2016).

23. Brod CS, Aleixo JA, Jouglard SD, et al. Evidence of dog as a reservoir for human leptospirosis: a serovar isolation, molecular characterization and its use in a serological survey Canine Leptospirosis. Rev Soc Bras Med Trop. 2005;38(4):294-300.

24. Ortega PA, Colín FRF, Gutiérrez BE, et al. Frequency and type of renal lesions in dogs naturally infected with leptospira species. Ann N Y Acad Sci. 2008;1149:270-274.

25. Stokes JE, Kaneene JB, Schall WD, et al. Prevalence of serum antibodies against six Leptospira serovars in healthy dogs. J Am Vet Med Assoc. 2007;230(11):1657-1664.

26. Gillespie J, Timoney JH, Timoney JF, et al. La Prensa Médica Mexicana México. 4th ed. Enfermedades Infecciosas de los Animales Domésticos. Mexico; 1981.

27. Low DG. Leptospirosis canina en: Terapéutica Veterinaria. Continental, México; 1981

28. Merchant IA, Packe RA. Acribia, Zaragoza, España. Bacteriología y Virológia Veterinarias. 1975.

29. Jansen A, Schoneberg I, Frank C, et al. Leptospirosis in Gsermany, $1962-$ 2003. Emerg Infec Dis. 2005;11(7):1048-1054.

30. Blood DC, Henderson JA, Radostis OM. Interamericana México, DF Medicina Veterinaria. 1983.

31. Duque BM, Moreno MJ, Gómez D. Leptospirosis en Edad Pediátrica. Infectología Práctica, México DF; 1988.

32. Vander Hoeden J. Epizootiology of Leptospirosis. Adv Vet Sci. $1958 ; 4: 278-339$.

33. Michna SW. Leptospirosis. Vet Rec. 1970;(86):484-496.

34. Timoney JF, Gillespie JH, Scott FW, et al. Microbiology and infectious diseases of domestic animals. The Spirochetes. 8th ed. In: Hagan, Bruner's, editors. Ithaca, USA: Comstock Publishing Associates; 1988. p. 45-57.
35. Prescott JF. Leptospirosis. 4th ed. In: Jubb KVF, Kennedy PC, editors. Patology of domestic animals. 1993. p. 503-511.

36. Hanson LE Ed. The Biology of Parasitic Spirochetes. USA: Academic Press; 1976.

37. Luna AMA, Moles CLP, Torres BJI. Leptospirosis un problema importante en perros. CENID-Microbiología INIFAP, SAGAR, DPA, UAM Xochimilco desplegable técnico. 1996.

38. Ward MP, Glickman L, Guptill LE. Prevalence of and risk factors for leptospirosis among dogs in the United States and Canada: 677 cases (1970-1998). J Am Vet Assoc. 2002;220(1):53-58.

39. Ward MP, Guptill LF, Wu CC. Evaluation of environmental risk factors for leptospirosis in dogs: 36 cases (1997-2002). J Am Vet Med Assoc. 2004;225(1):72-777.

40. Goldstein RE, Lin RC, Langston CE, et al. Influence of infecting serogroup on clinical features of leptospirosis in dogs. $J$ Vet Intern Med. 2006;20(3):489-494

41. Geinsen V, Stengel C, Brem S, et al. Canine leptospirosis infections clinical signs and outcome with different suspected Leptospira serogrups (42 cases). J Small Anim Pract. 2007;48(6):324-328.

42. Hernández Ramírez CV, Gaxiola Camacho SM, Osuna Ramirez I, et al. Prevalence and risk factors associated with serovars of Leptospira in dogs from Culiacan, Sinaloa. Veterinaria México OA. 2017;4(2):369.

43. Cárdenas MM, Vado SI, Ortega PA, et al. Prevalencia de leptospirosis canina en el municipio de Mérida Yucatán. Enfermedades infecciosas y microbiología. 2003;23:3.

44. Davis MA, Evermann JF, Petersen CR, et al. Serological Survey for Antibodies to Leptospira in Dogs and Raccoons in Washington State. Zoonoses Public Health. 2008;55(8-10):436-444.

45. Luna AM, Moles CL, Gavaldón RD, et al. La leptospirosis canina y su problemática en México. Rev Salud Anim. 2008;30(1):1-11.

46. Kikuti M, Langoni H, Nóbrega DN, et al. Ocurrencia y factores de riesgo asociados con la leptospirosis canina. J Venom Anim Trop. 2012;30(1):1-11. 